\title{
Fungi colonizing of small balsam seeds (Impatiens parviflora DC.) seeds in Wigry National Park
}

\author{
Grzyby zasiedlające nasiona niecierpka drobnokwiatowego \\ (Impatiens parviflora DC.) w Wigierskim Parku Narodowym
}

\author{
Wojciech Pusz*, Katarzyna Patejuk, Agata Kaczmarek
}

\begin{abstract}
Summary
The aim of this study was to assess the extent of colonisation and also the species composition of the fungi colonising the seeds of small balsam (Impatiens parviflora) in the Wigry National Park. The test was carried out in the years 2018-2019. The seeds of I. parviflora were taken at full maturity, at the turn of August and September, from 6 locations in the first year of study and from 9 locations in the second year of study. In the first year the mycological analysis of Impatiens parviflora seeds allowed for isolating 18 species of fungi and 3 taxa referred to as non-cryptogamic or yeastlike and 22 species of fungi and 1 taxa referred to as non-cryptogamic in the second year of study. The highest share in the mycobiota of Impatiens seeds in most cases were Cladosporium genus fungi, primarily $C$. cladosporioides and $C$. herbarum, as well as Alternaria alternata. The varied degree of seed colonisation by fungi may be caused by environmental factors, nonetheless fungal species found in the spermosphere may limit the vigour of seeds, and thus reduce the I. parviflora population in a given area. However, to confirm this, further analysis is needed.
\end{abstract}

Key words: mycobiota, seed colonising fungi, invasive plants, Wigry

\section{Streszczenie}

Celem niniejszych badań była ocena stopnia zasiedlenia, a także składu gatunkowego grzybów zasiedlających nasiona niecierpka drobnokwiatowego w Wigierskim Parku Narodowym. Badania wykonano w latach 2018-2019. Nasiona Impatiens parviflora zostały pobierane w fazie dojrzałości pełnej, na przełomie sierpnia i września z 6 stanowisk w pierwszym roku badań i 9 stanowisk w drugim roku badań, zlokalizowanych na terenie Wigierskiego Parku Narodowego. Analiza mykologiczna z nasion I. parviflora pozwoliła na wyizolowanie łącznie 18 gatunków grzybów oraz 3 taksonów określanych mianem kolonii niezarodnikujących czy też drożdżoidalnych w roku 2018 oraz 22 gatunków grzybów oraz 1 taksonu określonego mianem kolonii niezarodnikującej w drugim roku prowadzenia badań. Największy udział w mykobiocie nasion roślin z rodzaju Impatiens, w większości przypadków stanowiły grzyby z rodzaju Cladosporium, przede wszystkim C. cladosporioides oraz C. herbarum, a także Alternaria alternata. Zróżnicowany stopień zasiedlenia nasion przez grzyby może być spowodowany czynnikami środowiskowymi, niemniej stwierdzone w spermosferze gatunki grzybów mogą wpływać na ograniczenie wigoru nasion, a tym samym zmniejszenie populacji I. parviflora na danym terenie. Jednak, aby to potwierdzić, konieczne jest przeprowadzenie dalszych analiz.

Słowa kluczowe: mykobiota, grzyby zasiedlające nasiona, rośliny inwazyjne, Wigry

\author{
Uniwersytet Przyrodniczy we Wrocławiu \\ Katedra Ochrony Roślin \\ pl. Grunwaldzki 24a, 50-363 Wrocław \\ *corresponding author: wojciech.pusz@upwr.edu.pl \\ ORCID: 0000-0003-1531-2739
}




\section{Wstęp / Introduction}

Rośliny inwazyjne są uważane za jedno z największych zagrożeń dla rodzimej flory (Najberek i Solarz 2016). Według szacunków Hulme (2007) nawet do 80\% roślin inwazyjnych dotarło do Europy ze względu na swoje walory dekoracyjne, pełniąc początkowo funkcje roślin ozdobnych. Z czasem część z nich, dzięki sprzyjającym warunkom, a także braku wrogów naturalnych rozprzestrzeniła się poza ogrody, spontanicznie zasiedlając nowe tereny. Ich niekontrolowane rozprzestrzenianie się na terenach seminaturalnych oraz naturalnych niejednokrotnie powoduje wypieranie rodzimych gatunków roślin, zanikanie cennych przyrodniczo siedlisk, a także niszczenie konstrukcji i budowli (Dajdok i wsp. 2011; Tokarska-Guzik i wsp. 2012). Organizmy obce stanowić mogą również pomost w rozprzestrzenianiu się gatunków pasożytniczych, zagrażających gatunkom rodzimym (Blackburn i Ewen 2016). Również w Polsce znane są sytuacje, gdy pomimo zaniku żywiciela pierwotnego (organizmu obcego), w nowym miejscu zostały jego pasożyty, osłabiając gatunki natywne (Solarz i Najberek 2017). Niekontrolowane rozprzestrzenianie się i rozwój roślin obcych może być również zagrożeniem fitosanitarnym, ze względu na przenoszenie i rozwój chorób oraz pasożytów roślin, w tym organizmów kwarantannowych. Rośliny inwazyjne stanowić mogą potencjalne źródła rozwoju organizmów zwalczanych na mocy prawa. Przykładem takiego organizmu kwarantannowego jest bakteria Xylella fastidiosa, rozwijająca się w kraju pochodzenia na wielu roślinach inwazyjnych dla naszej flory, m.in. dębie czerwonym (Quercus rubra) (Chang i Walker 1988), winobluszczu pięciolistkowym (Parthenocissus quinquefolia) i winobluszczu trójklapowym (P. tricuspidata) (Freitag 1951) oraz sumaku octowcu (Rhus typhina) (Hopkins i Adlerz 1988). Według szacowań Godefroid i wsp. (2019) podgatunek $X f$ subspecies multiplex zawędrować może również do naszego kraju, zagrażając nie tylko gatunkom inwazyjnym, ale przede wszystkim wielu macierzystym roślinom drzewiastym. Podobny scenariusz możliwy jest również w przypadku innych kwarantannowych agrofagów, znajdujących schronienie na gatunkach obcych.

Niektóre rośliny inwazyjne mogą być miejscem rozwoju chorób roślin ważnych z ekonomicznego punktu widzenia, np. rozwijająca się na takim gatunku jak czeremcha amerykańska Taphrina deformans (Pusz i wsp. 2019b), powodująca kędzierzawość liści brzoskwini, czy Monilinia linhartiana sprawca moniliozy na przedstawicielach rodzaju Prunus (Batra 1991). Znane są również natywne patogeny, jak Plasmopara obducens, sprawca mączniaka rzekomego na niecierpku, zwiększające swój potencjał inokulacyjny na inwazyjnych krewnych, zagrażające również roślinom ozdobnym (np. Impatiens walleriana) (Vajna 2011). Podobne zjawisko zaobserwowano w przypadku dębu czerwonego, który zasiedlany jest przez rodzime gatunki grzybów pasożytniczych, zaadaptowane do nowego żywiciela (Woziwoda i wsp. 2012).

Zwyczajowo, ze względu na wysoką żywotność i niekontrolowany rozwój, rośliny inwazyjne traktowane są często jak chwasty, a co się z tym wiąże, zmiany chorobowe okazjonalnie pojawiające się na nich, nie są zauważane przez ludzi. Mając jednak na względzie ochronę fitosanitarną, opartą na zasadach integrowanej ochrony roślin, niezbędnym wydaje się monitorowanie patogenów zasiedlających rośliny inwazyjne, aby w porę przeciwdziałać rozwojowi epidemii roślin uprawnych, co odnosić się może również do roślin ozdobnych.

Spośród polskich parków narodowych, w Wigierskim Parku Narodowym (WPN) stwierdzono największą liczbę gatunków roślin obcych i inwazyjnych - 72 gatunki, w tym 11 gatunków inwazyjnych (Dajdok i wsp. 2007; Najberek i Solarz 2011). Największą presję roślin inwazyjnych w WPN zaobserwować można na terenach ruderalnych, zasiedlanych m.in. przez nawłocie, rdestowca ostrokończystego oraz różę pomarszczoną. Duże znaczenie mają również drogi śródleśne, stanowiące tranzyt między terenami naturalnymi a ruderalnymi, przy których oprócz wyżej wymienionych gatunków spotkać można m.in. dąb czerwony, klon jesionolistny oraz czeremchę późną. Gatunki te wraz z niecierpkiem drobnokwiatowym dobrze odnajdują się w środowisku leśnym, zajmując tereny borów, grądów, łęgów, a nawet borealnej bagiennej świerczyny. Ze względu na duży udział wód w WPN, niektóre rośliny inwazyjne szczególnie zadomowiły się przy obrzeżach rzek oraz jezior. Wymienić wśród nich można: niecierpka gruczołowatego, różę pomarszczoną oraz klon jesionolistny (Dajdok i wsp. 2007).

Niecierpek drobnokwiatowy (Impatiens parviflora) uznawany jest za gatunek silnie ekspansywny, którego występowanie na obszarze Polski ma istotne znaczenie (kategoria IV inwazyjności). Przybył z Azji jako roślina ozdobna, która z czasem wraz z odpadami z ogrodów, transportem towarów i gleby zawierającej nasiona przedostała się do ekosystemów ruderalnych, a następnie leśnych. W Polsce pojawił się po raz pierwszy w okolicach Krakowa i Gdańska, w roku 1850. Obecnie rozprzestrzeniony jest na terenie całego kraju, jednak zdecydowanie częściej spotyka się go w południowej części. Zasiedla tereny zarówno antropogeniczne, semi-naturalne, jak i naturalne, zmieniając skład gatunkowy podszytu, a w warunkach silnego oświetlenia wypierając macierzysty gatunek Impatiens noli-tangere. Jest także gospodarzem wielu gatunków mszyc, w tym obcego pochodzenia, np. Impatientinum asiaticum, a także patogenów, np. Plasmopara obducens, mogących zagrażać pierwotnemu gatunkowi niecierpka (Adamowski i wsp. 2018).

Coraz więcej uwagi zwraca się na grzyby patogeniczne zasiedlające nasiona roślin inwazyjnych. Podejmowane są próby estymacji stopnia zadomowienia oraz rozwoju inwazji, 
na podstawie grup troficznych grzybów zasiedlających nasiona (Najberek i wsp. 2018).

Celem niniejszych badań była ocena stopnia zasiedlenia, a także składu gatunkowego grzybów zasiedlających nasiona niecierpka drobnokwiatowego, ze szczególnym zwróceniem uwagi na gatunki potencjalnie ograniczające wigor nasion i populację I. parviflora na terenie Wigierskiego Parku Narodowego.

\section{Materiały i metody / Materials and methods}

Badania wykonano w latach 2018-2019. Nasiona I. parviflora pobierano $\mathrm{w}$ fazie dojrzałości pełnej, na przełomie sierpnia i września z 6 stanowisk w pierwszym roku badań i 9 stanowisk w drugim roku badań, zlokalizowanych na terenie Wigierskiego Parku Narodowego (tab. 1). Uzyskane nasiona podzielono na dwie partie, po około 50 nasion z każdego stanowiska. Jedna z nich została wyłożona bezpośrednio na szalki Petriego $\mathrm{z}$ agarem glukozowo-ziemniaczanym (PDA - Potato Dextrose Agar) firmy Biocorp. Pozostałe nasiona przed wyłożeniem na pożywkę, zostały odkażone powierzchniowo $1 \%$ roztworem podchlorynu sodu przez 30 sekund. Dzięki temu możliwa była izolacja grzybów zasiedlających wnętrze nasion. Wyrastające z nasion kolonie grzybów oznaczono do gatunku na podstawie cech morfologicznych (Pitt i Hocking 2009; Watanabe 2010).

\section{Wyniki i dyskusja / Results and discussion}

$\mathrm{Z}$ nasion I. parviflora wyizolowano łącznie 18 gatunków grzybów oraz 3 taksony określane mianem kolonii niezarodnikujących lub kultur drożdżoidalnych w roku 2018 (tab. 1) oraz 22 gatunki grzybów oraz 1 takson określony mianem kolonii niezarodnikującej $\mathrm{w}$ drugim roku prowadzenia badań (tab. 2). Nasiona były zasiedlone przez grzyby $\mathrm{w}$ różnym stopniu. $\mathrm{W}$ pierwszym roku badań, najniższym stopniem zasiedlenia cechowały się nasiona pobrane z osobników rosnących w rejonie Zatoki Słupiańskiej w WPN (80\% nasion zasiedlonych przez grzyby). Nasiona pobrane $\mathrm{z}$ tej lokalizacji, poddane powierzchniowemu odkażeniu charakteryzowały się niskim stopniem zasiedlenia, gdyż jedynie w 40\% prób stwierdzono występowanie grzybów. Podobnym stopniem zasiedlenia wewnętrznej części nasion charakteryzowały się próby zebrane w okolicy Suchara Rzepiskowego, a wyższym (65\%) na stanowisku w pobliżu miejscowości Gawrych Ruda. W pozostałych lokalizacjach wielkość zasiedlenia przez grzyby wynosiła od 80 do $100 \%$. W 2019 roku najniższym stopniem zasiedlenia wnętrza nasion charakteryzowały się nasiona pobrane $\mathrm{z}$ osobników rosnących w rejonie Suchara Rzepiskowego (20\% nasion zasiedlonych przez grzyby), na stanowisku 348 (35\% nasion zasiedlonych przez grzyby), a także w okolicy miej- scowości Gawrych Ruda (45\% nasion zasiedlonych przez grzyby). W pozostałych lokalizacjach wartość ta osiągała $50-100 \%$.

Najwięcej kolonii grzybów w obydwu latach badań uzyskano z nasion pobranych z roślin rosnących na Półwyspie Wigierskim, w okolicy Dyrekcji WPN w Krzywem oraz w okolicach wsi Sobolewo. Na tych stanowiskach w spermosferze wyraźnie dominował grzyb Alternaria alternata, który zasiedlał głównie powierzchnię zewnętrzną nasion. Podobna sytuacja miała miejsce w przypadku nasion zebranych z roślin rosnących w okolicy miejscowości Gawrych Ruda. W przypadku tego taksonu widać również jego dominację w roku 2018, słabiej zaznaczoną w kolejnym sezonie.

Największym udziałem wśród grzybów wyizolowanych z nasion roślin z rodzaju Impatiens, charakteryzowały się grzyby z rodzaju Cladosporium, przede wszystkim C. cladosporioides oraz C. herbarum. Masowo wystąpiły w drugim roku badań. Grzyby te są uważane za gatunki kosmopolityczne, stosunkowo elastyczne jeśli chodzi o temperaturę, preferują jednak wyższą wilgotność powietrza przy jednocześnie niższej temperaturze. Rozwijają się z reguły jako saprotrofy, zasiedlając martwe tkanki roślinne. Coraz częściej gatunki te rozważa się jako kompleks różnych taksonów (Bensch i wsp. 2012, 2018), w większości mogących być typowymi patogenami wielu gatunków roślin (Ogórek i wsp. 2012). Grzyby rodzaju Cladosporium chętnie zasiedlają nasiona wielu gatunków roślin, co znajduje swoje potwierdzenie w pracach innych autorów (Fakhrunnisa i wsp. 2006; Pusz 2009; Pusz i wsp. 2016). Jednak w zależności od warunków pogodowych panujących w sezonie wegetacyjnym, a także warunków zbioru nasion i ich dojrzałości, udział tych grzybów w mykobiocie może być różny (Pusz i wsp. 2016), co w przypadku powyższych badań miało znaczący wpływ na ostateczny wynik analizy mykologicznej. Należy jednak zauważyć, że przerastanie grzybni z rodzaju Cladosporium wewnątrz nasion występowało powszechnie, a grzyby te charakteryzowały się wysokim udziałem, także w przypadku powierzchniowego odkażania nasion. To z kolei może wpływać na wigor nasion i odnowienia roślin rodzaju Impatiens w przyszłości. $\mathrm{Z}$ drugiej jednak strony istnieją doniesienia na temat wpływu grzybów rodzaju Cladosporium na grzyby patogeniczne, takie jak np. Fusarium spp., gdzie wykazano ich pozytywny wpływ w ograniczaniu zasiedlenia nasion przez te gatunki (Liggitt i wsp. 1997). Znajduje to swoje potwierdzenie w uzyskanych danych, gdzie w przypadku nasion Impatiens balfourii pochodzących z Włoch, sporym udziałem charakteryzował się typowy patogen Giberella avenacea przy jednocześnie znikomym udziale grzybów rodzaju Cladosporium (Najberek i wsp. 2018).

W tych samych badaniach (Najberek i wsp. 2018) $\mathrm{z}$ nasion Impatiens glandulifera oraz Impatiens balfourii zebranych w Szwajcarii, licznie wyizolowali A. alterna- 


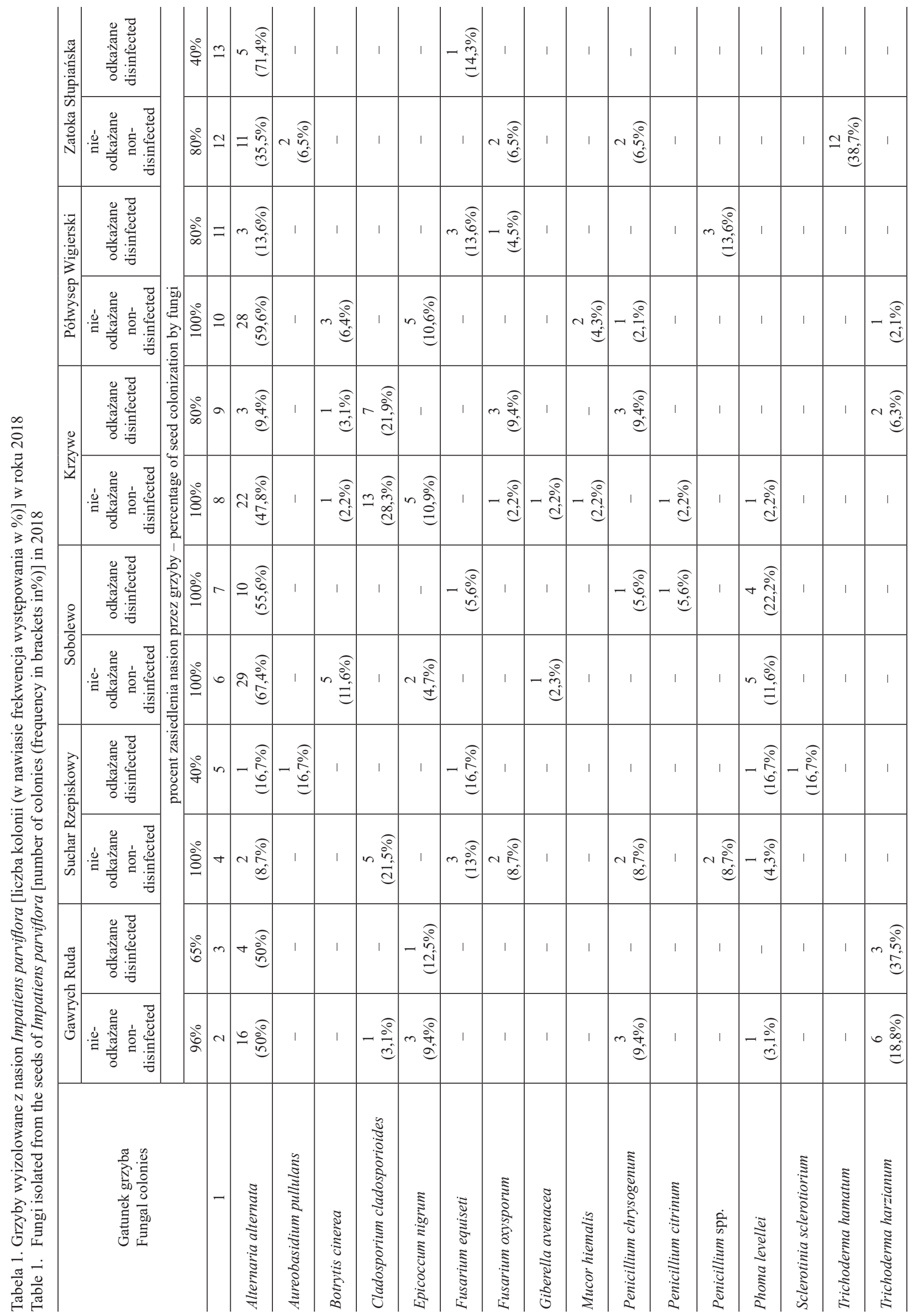




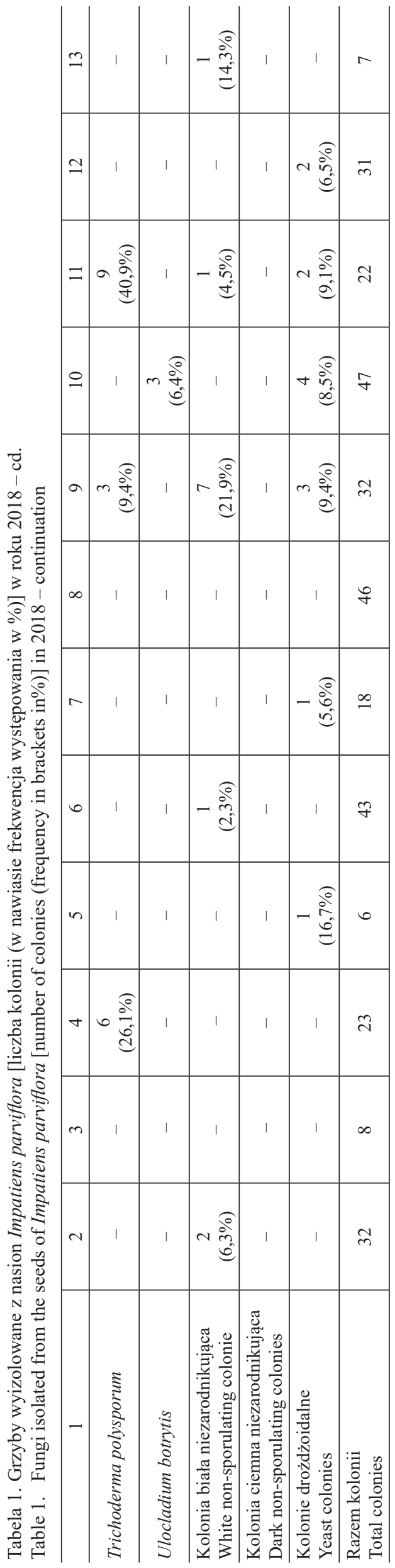

\begin{tabular}{|c|c|c|c|c|c|c|c|c|}
\hline \multirow{2}{*}{ 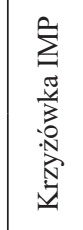 } & 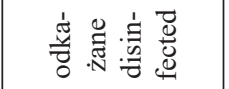 & ठे & 2 & $\begin{array}{cc}\widehat{\sigma} \\
n & \mathfrak{d} \\
& \mathfrak{d}\end{array}$ & 1 & 1 & $-\hat{\sigma}$ & 1 \\
\hline & 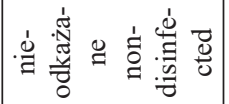 & 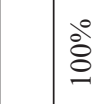 & $\simeq$ & n $\underset{\mathscr{G}}{\stackrel{6}{\sigma}}$ & । & 1 & $n$ r & 1 \\
\hline \multirow{2}{*}{$\stackrel{\infty}{m}$} & 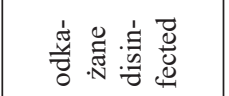 & iें & $=$ & 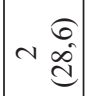 & 1 & I & $+\underset{\hat{n}}{\overparen{a}}$ & 1 \\
\hline & 窎 & छे & $\because$ & 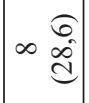 & 1 & 1 & $m$ 㿣 & । \\
\hline \multirow{2}{*}{ 商 } & 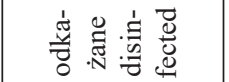 & iे & $\because$ & i $\frac{\widehat{్}}{\hat{\sigma}}$ & $-\frac{\hat{\theta}}{0}$ & 1 & 1 & 1 \\
\hline & 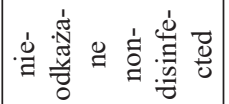 & $\underbrace{\infty}_{0}$ & \pm & $\sim \widehat{气}$ & 1 & 1 & 1 & 1 \\
\hline \multirow{2}{*}{ 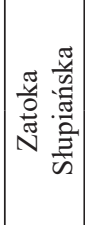 } & 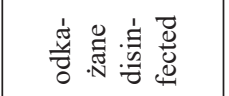 & 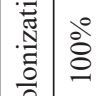 & $=$ & 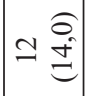 & 1 & 1 & $=\begin{array}{l}\widehat{\infty} \\
\mathfrak{d}\end{array}$ & 1 \\
\hline & 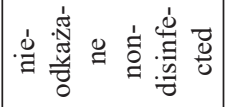 & 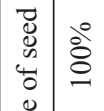 & $\simeq$ & $-\stackrel{\widehat{d}}{\stackrel{d}{d}}$ & 1 & 1 & $\operatorname{n} \frac{\widehat{?}}{=}$ & I \\
\hline \multirow{2}{*}{ 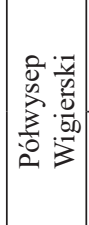 } & 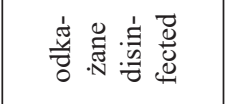 & 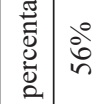 & $=$ & ○㣽 & 1 & 1 & $0 \underset{d}{\stackrel{f}{d}}$ & । \\
\hline & 总 & 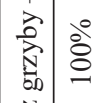 & $\circ$ & $\approx \begin{array}{ll}\infty \\
\approx & 0 \\
0\end{array}$ & । & I & 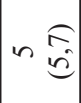 & । \\
\hline \multirow{2}{*}{ 泀 } & 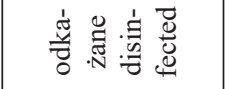 & 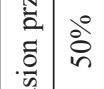 & $a$ & 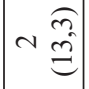 & I & 1 & I & I \\
\hline & 岛 & 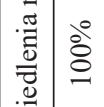 & $\infty$ & I & I & 1 & & 1 \\
\hline \multirow{2}{*}{$\begin{array}{l}0 \\
3 \\
0 \\
0 \\
0 \\
0 \\
0\end{array}$} & 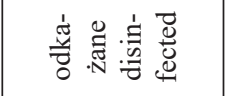 & 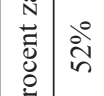 & - & $\mid \begin{array}{c}\tilde{n} \\
0 \\
0 \\
0 \\
0\end{array}$ & $\sim \stackrel{\varepsilon}{=}$ & 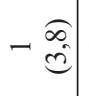 & $\sim \stackrel{E}{\Xi}$ & $-\stackrel{\infty}{\infty}$ \\
\hline & 离 & ठे & 0 & $\infty \stackrel{\hat{0}}{-}$ & 1 & 1 & $-\stackrel{6}{=}$ & । \\
\hline \multirow{2}{*}{ 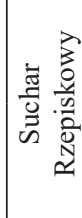 } & 旁 & ذें & in & । & 1 & 1 & 1 & 1 \\
\hline & 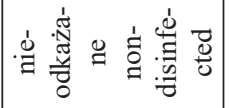 & ڤ̊ํํ & + & $\begin{array}{ll}0 & 0 \\
\infty & \stackrel{0}{0}\end{array}$ & । & 1 & $\sim \stackrel{\Im}{\stackrel{f}{\Xi}}$ & I \\
\hline \multirow{2}{*}{ 窇总 } & 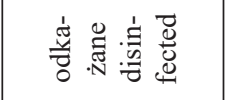 & 字 & $m$ & $\pm \stackrel{\hat{m}}{\tilde{d}}$ & $-\stackrel{E}{=}$ & 1 & $\ln \frac{\widehat{m}}{\infty}$ & । \\
\hline & 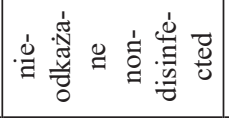 & ڤ̊ํํ & $\sim$ & 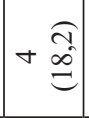 & 1 & 1 & $\operatorname{n} \underset{d}{\mathbb{d}}$ & । \\
\hline & 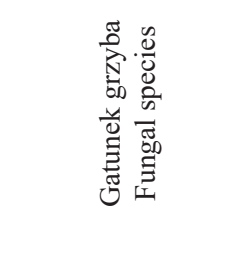 & & - & 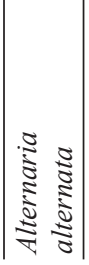 & 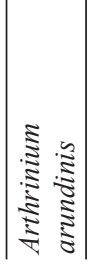 & 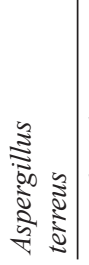 & 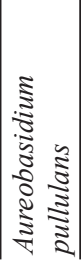 & 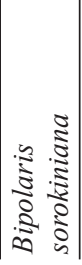 \\
\hline
\end{tabular}




\begin{tabular}{|c|c|c|c|c|c|c|c|c|c|c|c|c|c|c|c|c|c|c|c|}
\hline 2 & 1 & 1 & 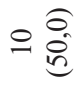 & 1 & 1 & 1 & 1 & 1 & 1 & 1 & 1 & $\left|\begin{array}{r}\sigma \\
-\hat{6}\end{array}\right|$ & $\begin{array}{ll}0 & \hat{0} \\
\sim & \stackrel{0}{\varrho}\end{array}$ & $-\begin{array}{c}\hat{\theta} \\
\hat{i}\end{array} \mid$ & 1 & I & 1 & 1 & ㄱ \\
\hline$\stackrel{\infty}{-}$ & $\begin{array}{r}6 \\
-6 \\
0\end{array}$ & 1 & 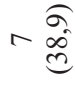 & 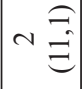 & 1 & 1 & 1 & 1 & 1 & I & 1 & $\begin{array}{c}-6 \\
-6 \\
0 \\
0\end{array}$ & 1 & 1 & 1 & $\begin{array}{r}\sigma \\
-\dot{6} \\
\dot{c}\end{array}$ & 1 & 1 & $\infty$ \\
\hline$=$ & 1 & 1 & 1 & 1 & 1 & 1 & 1 & 1 & 1 & 1 & $-\stackrel{\widetilde{m}}{\stackrel{\Xi}{ \pm}}$ & 1 & 1 & 1 & 1 & 1 & 1 & 1 & $r$ \\
\hline$\stackrel{0}{0}$ & $\begin{array}{r}6 \\
-6 \\
0\end{array}$ & $\begin{array}{r}6 \\
-6 \\
0\end{array}$ & 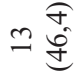 & $-\frac{6}{c} \mid$ & 1 & 1 & 1 & $\begin{array}{r}6 \\
- \\
-0\end{array}$ & 1 & 1 & 1 & 1 & 1 & 1 & 1 & 1 & 1 & 1 & $\stackrel{\infty}{\sim}$ \\
\hline$\because$ & 1 & 1 & in & 1 & 1 & 1 & 1 & 1 & 1 & 1 & m $\stackrel{\widehat{:}}{\stackrel{0}{0}}$ & 1 & 1 & 1 & 1 & 1 & 1 & $-\frac{\hat{e}}{\hat{e}}$ & $\because$ \\
\hline$\Xi$ & 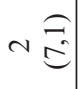 & 1 & $\simeq \widehat{\hat{I}}$ & $\sim \stackrel{\triangleq}{=}$ & 1 & 1 & $\begin{array}{r}6 \\
-6 \\
0\end{array}$ & 1 & 1 & 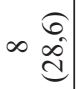 & 1 & 1 & 1 & 1 & 1 & $\begin{array}{r}6 \\
-6 \\
-0\end{array}$ & 1 & 1 & $\stackrel{\infty}{\sim}$ \\
\hline 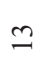 & $-\widehat{\widehat{A}}=$ & 1 & ले & $\sim \stackrel{\widehat{\widetilde{d}}}{\mathrm{~d}}$ & 1 & 1 & 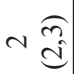 & 1 & 1 & 1 & $m \stackrel{n}{n}$ & $-\stackrel{\overparen{\overbrace{}}}{=} \mid$ & $-\stackrel{\widehat{\vartheta}}{=}$ & 1 & 1 & $\pm \widehat{\overparen{T}}$ & 1 & 1 & $\infty$ \\
\hline$\cong$ & 1 & I & $0 \stackrel{\hat{g}}{\hat{g}}$ & $\sim$ ब्रे & I & $-\underset{c}{f}$ & 1 & 1 & 1 & 1 & 1 & 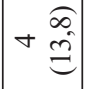 & $-\underset{f}{\hat{\imath}}$ & 1 & $-\stackrel{\widehat{c}}{\hat{c}}$ & $\sim \widehat{\widehat{\sigma}}$ & 1 & 1 & ते \\
\hline$=$ & 1 & $m \stackrel{E}{\tilde{\theta}}$ & $+\stackrel{\widehat{m}}{\stackrel{+}{=}}$ & $\begin{array}{r}0 \\
-0 \\
0\end{array}$ & 1 & 1 & 1 & 1 & $\begin{array}{l}6 \\
-0 \\
0\end{array}$ & 1 & 1 & I & m $\stackrel{E}{0}$ & 1 & 1 & 1 & 1 & 1 & $\stackrel{\infty}{\sim}$ \\
\hline ㅇ & 1 & 1 & 椧 & $m \underset{c}{\stackrel{f}{c}}$ & $m \underset{c}{\stackrel{f}{c}}$ & 1 & $-\widehat{=}$ & 1 & 1 & 1 & 1 & 1 & 1 & 1 & $-\widehat{=}$ & $m \underset{\mathscr{f}}{\stackrel{f}{c}}$ & $-\widehat{=}$ & 1 & $\infty$ \\
\hline$a$ & 1 & 1 & 1 & 1 & 1 & 1 & 1 & 1 & 1 & 1 & 1 & 1 & 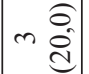 & $\mid \begin{array}{ll}0 & 0 \\
0 & 0 \\
\end{array}$ & 1 & 1 & 1 & 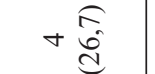 & $\because$ \\
\hline$\infty$ & 1 & 1 & 1 & $-\widehat{\hat{d}}$ & 1 & 1 & 1 & 1 & 1 & 1 & 1 & 1 & 1 & $\infty \begin{array}{ll} & \tilde{n} \\
& \tilde{y}\end{array}$ & 1 & 1 & 1 & ¿n & मे \\
\hline$r$ & 1 & 1 & $\wedge \widehat{\widehat{c}}$ & $-\begin{array}{c}\widehat{\infty} \\
-\hat{c}\end{array} \mid$ & 1 & 1 & 1 & 1 & $\begin{array}{c}-\widehat{\infty} \\
-\hat{c} \\
\hat{c}\end{array}$ & 1 & 1 & 1 & 1 & 1 & 1 & $-\begin{array}{c}\widehat{\infty} \\
-\hat{n}\end{array}$ & 1 & 1 & $\stackrel{0}{2}$ \\
\hline 0 & $-\stackrel{\sigma}{=}=$ & । & 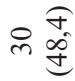 & 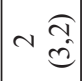 & 1 & 1 & $-\stackrel{6}{=}$ & 1 & 1 & 1 & 1 & 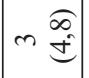 & 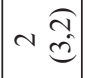 & I & 1 & 1 & 1 & $+\sqrt{n}$ & $\widetilde{\sigma}$ \\
\hline in & 1 & 1 & N & $\begin{array}{ll}\sim & \hat{0} \\
& 0 \\
0\end{array}$ & 1 & 1 & 1 & 1 & 1 & 1 & 1 & 1 & 1 & 1 & 1 & 1 & 1 & 1 & $\theta$ \\
\hline$\sigma$ & 1 & 1 & $\because \begin{array}{l}6 \\
\therefore \\
n\end{array}$ & 1 & 1 & 1 & 1 & $-\overrightarrow{\hat{n}}$ & 1 & 1 & 1 & । & 1 & 1 & 1 & $-\underset{\tilde{n}}{E}$ & 1 & 1 & $\hat{N}$ \\
\hline$m$ & 1 & 1 & $\stackrel{\infty}{\stackrel{\overbrace{}}{\hat{b}}}$ & $-\stackrel{E}{E}$ & 1 & $-\stackrel{E}{E}$ & 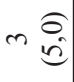 & 1 & 1 & 1 & 1 & $-\stackrel{E}{E}$ & 1 & 1 & $+\underset{E}{\hat{\theta}}$ & I & $-\stackrel{E}{=}$ & $-\stackrel{E}{=}$ & 8 \\
\hline$N$ & 1 & 1 & 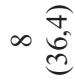 & 1 & 1 & 1 & 1 & 1 & 1 & 1 & 1 & $+\underset{\substack{0 \\
\infty}}{\stackrel{\infty}{=}}$ & $-\begin{array}{l}n \\
- \\
+\end{array}$ & 1 & 1 & 1 & 1 & 1 & ה \\
\hline- & 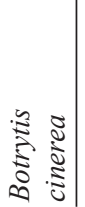 & 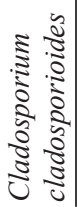 & 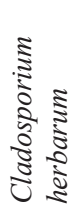 & 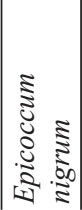 & 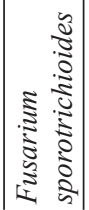 & 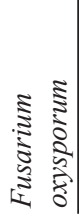 & 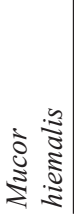 & 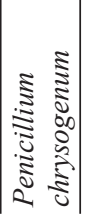 & 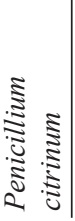 & 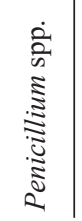 & 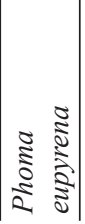 & 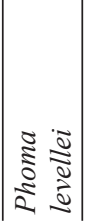 & 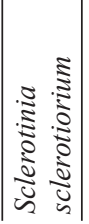 & 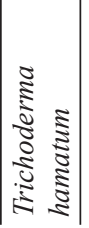 & 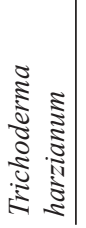 & 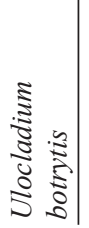 & 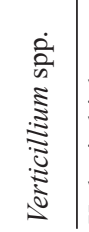 & 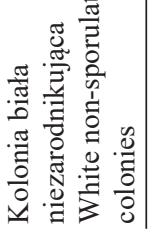 & 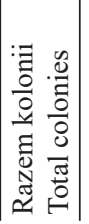 \\
\hline
\end{tabular}


ta. Grzyb ten jest typowym przedstawicielem zbiorowiska grzybów spermosfery (Jajor 2006; Logrieco i wsp. 2009). Również w przeprowadzonych badaniach zaobserwowano liczne występowanie tego gatunku na nasionach, sięgające niekiedy ponad 70\% wszystkich wyizolowanych kolonii. W roku 2018 \% udział A. alternata był większy niż w następnym roku, czego przyczyny można doszukiwać się w warunkach pogodowych, w tym suszy, która objęła swoim zasięgiem również Wigierski Park Narodowy w 2019 roku. Występowanie A. alternata na przechowywanych nasionach nie zawsze świadczy o złej jakości nasion, gdyż w niektórych przypadkach w swoisty sposób chroni powierzchnię nasiona przed zasiedleniem przez inne grzyby patogeniczne i nie wpływa negatywnie na wigor nasion (Liggitt i wsp. 1997; Pusz 2009).

Grupą grzybów, która w znaczący sposób wpływa na obniżenie jakości nasion, a co za tym idzie - także ich wigoru, są głównie grzyby rodzaju Fusarium (Jajor 2006; Pusz 2009; Kordas i wsp. 2015; Pusz i wsp. 2016). Wspomniany gatunek $G$. avenacea, jeden z najgroźniejszych patogenów roślin, stwierdzany w nasionach różnych gatunków roślin (Schaafsma i wsp. 2005; Gołębiowska i wsp. 2016), zaobserwowany został również w prezentowanych badaniach, w pierwszym roku badań. Powszechnie występuje on jako patogen glebowy, często zasiedlający nasiona roślin uprawnych. Potencjalnie może wywoływać zgorzele przedi powschodowe wielu roślin uprawnych i dzikorosnących, ograniczając również kiełkowanie nasion przez produkcję mykotoksyn (Leslie i Summerell 2006). Znacznie większy procentowy udział mieli inni przedstawiciele rodzaju $\mathrm{Fu}$ sarium, m.in.: F. equiseti (w 2018 r. stanowiący do $16 \%$ wszystkich wyizolowanych kolonii), F. oxysporum (2018 r. do 9\%, 2019 r. - do 3,4\%) oraz F. sporotrichioides w 2019 r. $(3,4 \%)$. W większości nie są to jednak taksony szczególnie groźne dla roślin, w większości bytujące na korzeniach i tkankach roślin jako saprotrofy, jako patogeny wtórne lub jako endofity (Leslie i Summerell 2006).

Na pojedynczych stanowiskach: w rejonie Suchara Rzepiskowego i Zatoki Słupiańskiej w pierwszym roku badań oraz w Krzywem w drugim roku badań, zaznaczona była obecność grzybów rodzaju Trichoderma. W obrębie tego rodzaju powszechnie znany są mechanizm mykopasożyt- nictwa, co wykorzystywane jest w rolnictwie i ogrodnictwie do zmniejszania zagrożenia ze strony patogenów, jako „biological agents”. Obecność Trichoderma sp. może również stymulować i wspierać do wzrostu roślinę zasiedlaną, działając niejako jak biostymulator (Herrera-Estrella i Chet 2004). Na chwilę obecną nie jest ona więc czynnikiem potencjalnie ograniczającym populację pozostałych gatunków grzybów, szczególnie patogenicznych dla niecierpka.

\section{Podsumowanie / Summary}

Jednym z celów badania zbiorowisk grzybów zasiedlających różne tkanki roślin inwazyjnych jest ciągłe poszukiwanie organizmów, które mogą być potencjalnymi tzw. „green agents" do biologicznego zwalczania ekspansywnych gatunków. Powyższe badania wskazują, że wyizolowane z nasion niecierpka drobnokwiatowego grzyby, mogą wpływać na wigor nasion, a tym samym dalsze rozprzestrzenianie się tej rośliny. Z drugiej jednak strony, skład gatunkowy mykobioty jest podobny do typowego zróżnicowania gatunkowego grzybów zasiedlających nasiona innych gatunków roślin, w tym roślin uprawnych. Ten fakt może z kolei wskazywać na wysoki stopień udomowienia niecierpka drobnokwiatowego w warunkach naszego kraju. Badania nad mykobiotą obcych roślin inwazyjnych stanowią punkt wyjścia do zrozumienia procesu inwazji oraz udomowienia nowych przedstawicieli flory. Liczba oraz skład gatunkowy grzybów spermosfery zmienia się z czasem rozwoju inwazji i stanowić może jeden z kluczowych punktów odniesienia w przypadku szacowania tempa inwazji oraz wzajemnych oddziaływań w ekosystemie (Najberek i wsp. 2018; Pusz i wsp. 2019a).

\section{Podziękowanie / Acknowledgements}

Badania sfinansowano ze środków funduszu leśnego Państwowego Gospodarstwa Leśnego „Lasy Państwowe” przekazanych Wigierskiemu Parkowi Narodowemu w latach 2018-2019 zgodnie z numerami umów EZ.0290.1.36.2018 i EZ.0290.1.20.2019.

\section{Literatura / References}

Adamowski W., Chmura D., Hołdyński C. 2018. Impatiens parviflora DC - Karta informacji gatunku. Generalna Dyrekcja Ochrony Środowiska. www.projekty.gdos.gov.pl/igo [dostęp: lipiec 2019].

Batra L.R. 1991. World species of Monilinia (fungi): their ecology, biosystematics and control. Mycologia Memoir 16, 246 ss.

Bensch K., Braun U., Groenewald J.Z., Crous P.W. 2012. The genus Cladosporium. Studies in Mycology 72 (1): 1-401. DOI: 10.3114/ $\operatorname{sim} 0003$

Bensch K., Groenewald J.Z., Meijer M., Dijksterhuis J., Jurjević Ž., Andersen B., Houbraken J., Crous P.W., Samson R.A. 2018. Cladosporium species in indoor environments. Studies in Mycology 89: 177-301. DOI: 10.1016/j.simyco.2018.03.002

Blackburn T.M., Ewen J.G. 2016. Parasites as drivers and passengers of human-mediated biological invasions. EcoHealth 14: 61-73. DOI: 10.1007/s10393-015-1092-6

Chang C.J., Walker J.T. 1988. Bacterial leaf scorch of northern red oak: isolation, cultivation, and pathogenicity of xylem-limited bacterium. Plant Disease 72: 730-733. DOI: 10.1094/PD-72-0730 
Dajdok Z., Krzysztofiak A., Krzysztofiak L., Romański M., Śliwiński M. 2007. Rośliny inwazyjne w Wigierskim Parku Narodowym, Krzywe, 24 ss. http://www.wigry.org.pl/inwazyjneWPN.pdf [dostęp: 13.10.2019].

Dajdok Z., Śliwiński M., Romański M., Krzysztofik A., Krzysztofik L. 2011. Gatunki inwazyjne jako zagrożenie dla bioróżnorodności. W: Poradnik dla pracowników parków narodowych. Edycja 4. Wigierski Park Narodowy, Krzywe. http://www.wigry.org.pl/inf_i_rozw/ budowa_por/por4_4.htm [dostęp: 13.10.2019].

Fakhrunnisa, Hashmi M.H., Ghaffar A. 2006. Seed-borne mycoflora of wheat, sorghum and barley. Pakistan Journal of Botany 38 (1): $185-192$.

Freitag J.H. 1951. Host range of the Pierce's disease virus of grapes as determined by insect transmission. Phytopathology 41 (10): 920-934.

Godefroid M., Cruaud A., Streito J.-C., Rasplus J.-Y., Rossi J.-P. 2019. Xylella fastidiosa: climate suitability of European continent. Scientific Reports 9: 8844. DOI: 10.1038/s41598-019-45365-y

Gołębiowska H., Pląskowska E., Weber R., Kieloch R. 2016. The effect of soil tillage and herbicide treatments on the incidence of Fusarium fungi genus in the grain of rye. Plant, Soil and Environment 62 (10): 435-440. DOI: 10.17221/647/2015-PSE

Herrera-Estrella A., Chet I. 2004. The biological control agent Trichoderma from fundamentals to applications. s. 147-156. W: Fungal Biotechnology in Agricultural, Food and Environmental Applications (D.K. Arora, red.). Marcel Dekker, Inc., New York, Basel, 475 ss. ISBN 0-8247-4770-4.

Hopkins D.L., Adlerz W.C. 1988. Natural hosts of Xylella fastidiosa in Florida. Plant Disease 72: 429-431. DOI: 10.1094/PD-72-0429

Hulme P.E. 2007. Biological invasions in Europe: drivers, pressures, states, impacts and responses. Chapter 3. s. 56-80. W: Biodiversity Under Threat (R.E. Hester, R.M. Harrison, red.). Cambridge, UK, Cambridge University Press, 290 ss. ISBN 978-0-85404-251-7. DOI: $10.1039 / 9781847557650-00056$

Jajor E. 2006. Zasiedlenie przez grzyby nasion odmian populacyjnych i mieszańcowych rzepaku pochodzących ze zbioru 2004 roku. [Colonisation of seeds of open-pollinated and hybrid oilseed rape cultivars from 2004 harvest]. Progress in Plant Protection/Postępy w Ochronie Roślin 46 (2): 572-575.

Kordas L., Pusz W., Czapka T., Kacprzyk R. 2015. The effect of low-temperature plasma on fungus colonization of winter wheat grain and on seed quality. Polish Journal of Environmental Studies 24 (1): 433-438.

Leslie J.F., Summerell B.A. 2006 The Fusarium Laboratory Manual. Blackwell Publishing, Hoboken, 388 ss. ISBN 978-0-813-81919-8.

Liggitt J., Jenkinson P., Parry D.W. 1997. The role of saprophytic microflora in the development of Fusarium ear blight of winter wheat caused by Fusarium culmorum. Crop Protection 16 (7): 679-685. DOI: 10.1016/S0261-2194(97)00039-2

Logrieco A., Moretti A., Solfrizzo M. 2009. Alternaria toxins and plant diseases: an overview of origin, occurrence and risks. World Mycotox Journal 2 (2): 129-140. DOI: 10.3920/WMJ2009.1145

Najberek K., Pusz W., Solarz W., Olejniczak P. 2018. The seeds of success: release from fungal attack on seeds may influence the invasiveness of alien Impatiens. Plant Ecology 219 (10): 1197-1207. DOI: 10.1007/s11258-018-0872-9

Najberek K., Solarz W. 2011. Inwazje biologiczne w polskich parkach narodowych i krajobrazowych. s. 624-639. W: Księga gatunków obcych inwazyjnych w faunie Polski (Z. Głowaciński, H. Okarma, J. Pawłowski, W. Solarz, red.). Instytut Ochrony Przyrody Polskiej Akademii Nauk, Kraków.

Najberek K., Solarz W. 2016. Gatunki obce. Przyczyny inwazyjnych zachowań i sposoby zwalczania. [Alien species. Causes of invasiveness and control methods]. Kosmos Problemy Nauk Biologicznych 65 (1): 81-91.

Ogórek R., Lejman A., Pusz W., Miłuch A., Miodyńska P. 2012. Characteristics and taxonomy of Cladosporium fungi. [Charakterystyka i taksonomia grzybów z rodzaju Cladosporium]. Mikologia Lekarska 19 (2): 80-85.

Pitt J.I., Hocking A.D. 2009. Fungi and Food Spoilage. Springer, New York, 520 ss. ISBN 978-0-387-92206-5. DOI: 10.1007/978-0-38792207-2

Pusz W. 2009. Fungi from seeds of Amaranthus spp. [Grzyby zasiedlające nasiona roślin rodzaju Amaranthus]. Phytopathologia 54: $15-21$.

Pusz W., Baturo-Cieśniewska A., Patejuk K., Zwijacz-Kozica T. 2019a. Ocena zdrowotności liści rdestowca ostrokończystego (Reynoutria japonica Houtt.) w wybranych lokalizacjach Tatrzańskiego Parku Narodowego i Wigierskiego Parku Narodowego. [Evaluation of health conditions of leaves of Japanese knotweed (Reynoutria japonica Houtt.) in selected locations of Tatra National Park and Wigry National Park]. Progress in Plant Protection 59 (1): 27-31. DOI: 10.14199/ppp-2019-004

Pusz W., Mascher F., Czembor E., Czembor J., Ogórek R. 2016. Characterization of the relationships between wheat cultivars, Fusarium head blight, and mycoflora grains. Polish Journal of Environmental Studies 25 (3): 1373-1380. DOI: 10.15244/pjoes/61880

Pusz W., Patejuk K., Kaczmarek A., Baturo-Cieśniewska A. 2019b. Grzyby pasożytnicze występujące na wybranych gatunkach roślin inwazyjnych w Wigierskim Parku Narodowym. s. 534-538. W: Prace naukowo-badawcze realizowane w latach 2012-2018 w polskich parkach narodowych współfinansowane ze środków funduszu leśnego przekazanych przez Lasy Państwowe. Materiały konferencyjne „Rola funduszu leśnego w rozwoju badań naukowych w parkach narodowych”. Gawrych Ruda, 24-25 października 2019 r., 572 ss.

Schaafsma A.W., Tamburic-Ilincic L., Hooker D.C. 2005. Effect of previous crop, tillage, field size, adjacent crop, and sampling direction on airborne propagules of Gibberella zeae/Fusarium graminearum, fusarium head blight severity, and deoxynivalenol accumulation in winter wheat. Canadian Journal of Plant Pathology 27 (2): 217-224. DOI: 10.1080/07060660509507219

Solarz W., Najberek K. 2017. Alien parasites may survive even if their original hosts do not. EcoHealth 14 (1): S3-S4. DOI: 10.1007/ s10393-016-1128-6

Tokarska-Guzik B., Dajdok Z., Zając M., Zając A., Urbisz A., Danielewicz W., Hołdyński C. 2012. Rośliny obcego pochodzenia w Polsce ze szczególnym uwzględnieniem gatunków inwazyjnych. Generalna Dyrekcja Ochrony Środowiska, Warszawa, 197 ss. ISBN $978-$ 83-62940-34-9

Vajna L. 2011. First report of Plasmopara obducens on impatiens (Impatiens walleriana) in Hungary. New Disease Reports $24: 13$. DOI: $10.5197 / j .2044-0588.2011 .024 .013$

Watanabe T. 2010. Pictorial Atlas of Soil and Seed Fungi. Morphologies of Cultured Fungi and Key to Species. Third Edition. CRC Press, Washington, 426 ss. ISBN 978143980419.

Woziwoda B., Kałucka I., Ruszkiewicz-Michalska M., Sławska M., Sławski M., Tołoczko W., Hachułka M., Kopeć D., Rosadziński S., Witkowski J. 2012. Interdyscyplinarne badania ekologicznych skutków introdukcji dębu czerwonego Quercus rubra L. w lasach Polski środkowej - założenia i cele projektu. [Interdisciplinary research of ecological effects of northern red oak Quercus rubra L. introduction in forest ecosystems (Central Poland) - the principles and aims of study]. Studia i Materiały Centrum Edukacji Przyrodniczo-Leśnej w Rogowie 33 (4): 178-189. 